\title{
Use of Near-Infrared Spectroscopy in the Management of Patients in Neonatal Intensive Care Units - An Example of Implementation of a New Technology
}

\author{
Barbara Engelhardt and Maria Gillam-Krakauer \\ Vanderbilt University, Nashville, TN
}

USA

\section{Introduction}

Near-infrared spectroscopy (NIRS) is a spectroscopic technique which uses the NIR region of the electromagnetic spectrum to gain information about natural samples through their absorption of NIR light. This method is used in several branches of science. In medicine, it was first used in adult patients, who were placed on by-pass during cardiac surgery to follow cerebral oxygenation, cerebral rSO2 (rSO2-c,) and thereby perfusion and metabolism of the brain. Its many other possibilities soon became apparent. Although the brain remains the main organ of interest in patients of all ages, other tissues are being studied as well. Aside from cardiac surgery clinicians in specialties such as sports medicine, plastic surgery (to assess flap viability), and neonatology apply NIRS in clinical settings. (Feng et al., 2001)

By the late 1980's the first studies on monitoring of regional oxygenation in the neonatal brain were published. (Delpy et al., 1987; Edwards et al., 1988) In 2004 on average one new article on NIRS was published in Pub Med every day. (Ferrari et at, 2004) Monitoring of vital signs in the ICUs has scientific and patient care related goals. One may be able to gain better understanding of physiology and be alerted to changes in patient status to be able to respond immediately.

The vulnerability of the neonate, especially of the newborn brain, to changes in oxygenation is an ever present concern as it is linked to long-term outcome. For that reason neonatologists are obligated to find ways to monitor their patients to be ahead of evolving pathology and avoid the severe impact of negative events.

As early as 1999 the NINDS and NIH hosted a workshop for experts in the fields of neurology and neonatology to discuss the use of NIRS for cerebral monitoring in infants. The panel determined that the best NIRS instrument should be selected and used in longitudinal, blinded studies. Obtained data would need to be compared with short term, intermediate and long term outcomes. The questions the panel suggested to investigate were the predictive value of NIRS and its usefulness in leading to timely interventions and prevention of long term injury. (www.ninds.nih.gov/news_andevents/proceedings/ 
nirswkshop1999.htm) Once NIRS monitors became commercially available a few animal and many clinical trials were conducted. The clinical investigations were for the most part small, brief observational prospective studies. Also NIRS was introduced into daily practice by others at that time, years before normative data and validation studies had been obtained.

There is great potential to use the NIRS technology in the neonatal intensive care unit (NICU) since it is a portable, continuous, non-invasive bedside monitoring technique. Following the development of small and skin friendly sensors and FDA approval of some NIRS monitors for use in neonates, both research and clinical use of NIRS in the NICU increased exponentially. The number of research projects over the last 5-10 years is large. However, the trials, while dealing with questions important to understanding physiology and clinical care in the NICU, are small and almost exclusively conducted at single centers. Often no more than 10-20 patients are being followed. Very large NIRS related studies enrolled 40-90 patients. Many of the observations reported are of brief sampling periods, sometimes being no more than spot samples.

This chapter is a limited overview for non-clinicians such as engineers and science students, or clinicians who want to learn about a medical application of NIRS. The recent introduction of the NIRS technology into neonatal medicine is used as an example of how a new device came into use into use in the clinical setting over the last decade. Main areas of clinical use and supporting studies will be mentioned. Limitations of NIRS technology and controversies as well as future directions will be addressed. With the abundance of available literature this chapter cannot claim to be a reference. This is an exciting and rapidly advancing field with new studies published even as this article was sent to press. This chapter will demonstrate how a new technology is adopted into medical care, in this case the NICU.

\subsection{Materials}

Pub Med and Google have been queried regarding NIRS in NICUs, abdominal/splanchnic, cerebral and renal measurements, utility, and of NIRS use as prognosticator.

\subsection{Technology and measurements}

The principle of how NIRS works in humans was excellently summarized by Cohn:

Near-infrared spectroscopy has been used as a tool to determine the redox state of lightabsorbing molecules. This technology is based on the Beer-Lambert Law, which states that light transmission through a solution with a dissolved solute decreases exponentially as the concentration of the solute increases. In mammalian tissue, only three compounds change their spectra when oxygenated: cytochrome aa3, myoglobin, and hemoglobin. Because the absorption spectra of oxyhemoglobin and deoxyhemoglobin differ, their relative concentrations within tissue change with oxygenation, and the relative concentrations of the types of hemoglobin can be determined. Because NIRS measurements are taken without regard to systole or diastole, and because only $20 \%$ of blood volume is intra-arterial, spectroscopic measurements are primarily indicative of the venous oxyhemoglobin concentration. In the near infrared region $(700-1,000 \mathrm{~nm})$, light transmits through skin, bone, and muscle without attenuation. (Cohn et al., 2003) There are several FDA approved 
NIRS monitors with somewhat different technology and algorithms available commercially (Wolf \& Greisen, 2009) to measure the venous weighted regional oxygen saturation (rSO2) or tissue oxygenation index (TOI).

Due to the small size and the thin covering layers of tissue of both term and preterm neonates, r-SO2/TOI measurements at a depth of 2-3 cm can reach brain, kidney, gut/ splanchnic circulation, liver and muscle. The access to these critical organs promises valuable physiologic information through monitoring by NIRS. Measurements of several sites can be recorded simultaneously. (Hoffman et al., 2003; McNeill et al., 2010, 2011)

NIRS measurements are organ specific and regional (rSO2), reflecting perfusion and metabolism by non-invasive measurement in real-time. They are not temperature, pulsatility or flow dependent. Thus they may offer advantages over traditional measures of perfusion such as capillary refill, blood pressure, and urine output, lactate, venous and arterial $\mathrm{O} 2$ which tend to alert the clinician once the disease process is further progressed. R-SO2 measurements cannot stand alone. While they may often be the first sign of change, they need to be interpreted in the context of other measurements such as mean arterial blood pressure (MABP), pulse oximetry (O2sat), blood gases, additionally in the research setting with measurements of cerebral blood flow (CBF) and cerebral blood volume (CBV). Evaluation of the link between the venous weighted NIRS readings and peripheral pulse oximetry, a measure of arterial O2, gives insight into oxygen supply and demand. Using a simple equation, the fractional extraction of oxygen $(\mathrm{FTOE}=\mathrm{SaO} 2-\mathrm{rSO} 2 / \mathrm{SaO} 2)$ oxygen consumption can be calculated and oxygen supply can be assessed. (Lemmers et al., 2006)

\subsection{Validation}

NIRS was implemented by many enthusiastic clinicians without a vast body of previous research evidence. This phenomenon may be representative of an era of limited funding for larger studies linked with the promise of a non-invasive "safe" monitoring technology.

Before human application the initial research applying NIRS to measure rSO2 technology in the medical field occurred in the laboratory: One of the first examples of validation used a phantom brain model in which $\mathrm{O} 2, \mathrm{~N} 2$, and $\mathrm{CO} 2$ content of a blood perfusate could be altered during measurements. The results correlated with findings in animal models. (Kurth et al., 1995) Later NIRS was further validated for the neonatologist in a newborn piglet model. The carotid, renal and mesenteric arteries were occluded and reperfused. These interventions led to rapid, simultaneous changes in rSO2 of the affected end-organs. (Wider, 2009) Furthermore, there have been validations in patients during intensive care, extracorporeal membrane oxygenation (ECMO) and cardiac surgery by comparing central blood samples with NIRS values. (Abdul-Khaliq et al., 2002; Benni et al., 2005; Nagdyman et al., 2004; Rais-Bahrami K et al, 2006; Weiss, 2005) Menke found reproducibility to be good as well. (Menke et al., 2003). The accuracy of data is impacted by light scattering, hemoglobin concentration and chromophores such as melanin and bilirubin. In the presence of a thicker overlying tissue layer, such as severe subcutaneous edema or excess subcutaneous fat, it may be impossible for the NIR light beam to reach the target organ. In the newborn modest changes in weight have a small effect on abdominal measurements while changes in hemoglobin over the first weeks of life can change measurements by $30-50 \%$. (Ferrari et al., 
2004; Madsen et al., 2000; McNeill et al., 2010, 2011; Wassenaar et al., 2005) NIRS measurements may differ between probes. (Sorensen et al., 2008)

\subsection{Safety and feasibility}

Commercially available sensors for neonates have become well tolerated due to smaller size and being lined with a skin friendly adhesive. To provide further skin protection in extremely premature patients probes can be attached to a light-permeable skin barrier without interference with measurements. (McNeill et al., 2010, 2011)

\subsection{Monitoring}

Organs which can be monitored in neonates are brain, kidney, gut, liver and muscle. This chapter will comment on the most commonly used sites- the brain, kidney and gut.

\section{Cerebral NIRS}

The neonatal period is a unique time in life as the infant undergoes dramatic physiologic changes during transition from intra- to extra-uterine life, which involve hemodynamics and affect oxygenation, reflected in rSO2. Due to its vulnerability the neonatal central nervous system is the main area of interest for measurements of oxygenation. The majority of articles written on the clinical use of NIRS in neonates include reports on cerebral measurements (crSO2 or cerebral Tissue Oxygenation Index (TOI)).

\subsection{Effect of gestational and postnatal age}

The largest body of research investigates cerebral NIRS values. Reports regarding effects of gestational age (pre-term, term, post-term) and postnatal/chronologic age on NIRS values are conflicting.

In a study by McNeill, which was blinded to caregivers and sampled from birth for a maximum of 21 days, baseline rSO2 for preterm infants (gestational age of 29-34 weeks) differed from established pediatric norms, while values for term neonates in the first days of life did not (McNeill et al., 2010, 2011). The observation by McNeill (McNeill et al., 2010, 2011) that cerebral NIRS decreases over time are supported by Roche-Labarbe's findings following weekly spot samples during the first 6 weeks obtained with a different study protocol and different NIRS equipment. (Roche-Labarbe et al., 2010, 2011) Both observations contradict Lemmers' study in which twice daily 60 minute sampling periods found no observed change. (Lemmers et al., 2006)

Naulears found an increase in cerebral oxygenation in premature infants during the first three days. In this study sampling periods were $30 \mathrm{~min}$. NIRS recordings occurred with a different instrument. (Naulaers et al., 2002) Meek's earlier report from 1998 in ventilated babies used NIRS and found an increase in cerebral blood flow over time. (Meek et al., 1998)

A study measuring rSO2-c in transition after delivery found by minute 3 that $\mathrm{rSO} 2$ increased and reached a plateau by minute 7. (Urlesberger et al., 2010)

More recently, Takami followed cerebral TOI in extremely low birth weight infants (ELBWs) at $3-6 \mathrm{~h}$ followed by samples every $6 \mathrm{~h}$ up to $72 \mathrm{~h}$. He observed a decrease in measurements until $12 \mathrm{~h}$, then an increase that correlated with similar changes in SVC flow. (Takami et al., 2010). 
When reviewing this literature regarding the contradicting study results, possible explanations present themselves: Patient populations are not identical. Protocols vary from study to study. Different sampling times may play an important role in influencing results, especially when spot samples versus long-term continuous data were collected. If studies were not blinded, care giving and subsequently observations might have been influenced. The use of different monitors and probes and probe placement may further lead to different results. Studies were small and data inconclusive. There was some agreement regarding abnormally low values being linked to poor outcome. (Dullenkopf et al., 2003; Sorensen et al., 2008; van Bel et al., 2008; Wolf \& Greisen, 2009, also see cerebral hypoxia)

\subsection{Variability}

Variability is the change in percent of $\mathrm{rSO} 2$ away from a calculated baseline. It can be followed over time to know how much time the rSO2 was above or below baseline. The baseline differs from patient to patient. Variability is an area of interest and needs further investigation: Cerebral daily variability is small. Large changes $(>20 \%)$ off the baseline would raise concern for acute clinical change. (McNeill et al., 2010, 2011) Change in variability may be an indicator of infection (Yanowitz et al., 2006). The change in baseline over the first weeks of life, which is observed in preterm infants, may represent ongoing developmental maturation independent of feeding status. (McNeill et al., 2010, 2011)

\subsection{Peripheral blood pressure and oxygenation, impact on autoregulation}

In the research setting cerebral blood flow and blood volume measurements, oxy- and deoxy hemoglobin and fractional extraction of oxygen (FTOE) as well as blood gas samples from central catheters added to detailed understanding of physiology.

Adequate $\mathrm{O} 2$ delivery to the brain tissue is most critical. Assessment of $\mathrm{O} 2$ delivery and consumption help understand clinical scenarios and their underlying pathophysiology: At the bed side this evaluation can occur by following changes in cerebral rSO2, changes in BP, oxygenation and peripheral blood gases. The below clinical scenarios for monitoring are amongst the more common:

Cerebral autoregulation is a homeostatic phenomenon controlled by the main capacitance vessels in the cerebral circulation. Through dilatation and constriction of these vessels cerebral blood flow and cerebral rSO2 or TOI are maintained at a steady level over a range of changing mean arterial blood pressures (MABP). This range is narrower in neonates, particularly in preterm infants. Cerebral pressure-passivity or loss of autoregulation is associated with low gestational age, low birth weight and systemic hypotension in a large study of 90 patients. (Soul et al., 2007)

If rSO2 or TOI changes correlate with the wave form of MABP autoregulation is lost. Swings in peripheral perfusion will be mirrored in cerebral blood flow and regional saturation readings. This phenomenon, when profound, carries an increased risk for intra-ventricular hemorrhage (IVH) and peri-ventricular leucomalacia (PVL) in preterm infants and generally a poor prognosis for neurodevelopment outcome. The more swings or changes in mean arterial pressure (MAP) and NIRS coincide and mirror each other, the more the waves are in concordance. Several studies link concordance with a more unfavorable prognosis and a higher likelihood of death. (Caicedo et al., 2011; DeSmet et al., 2010; Greisen \& Borch, 2001; 

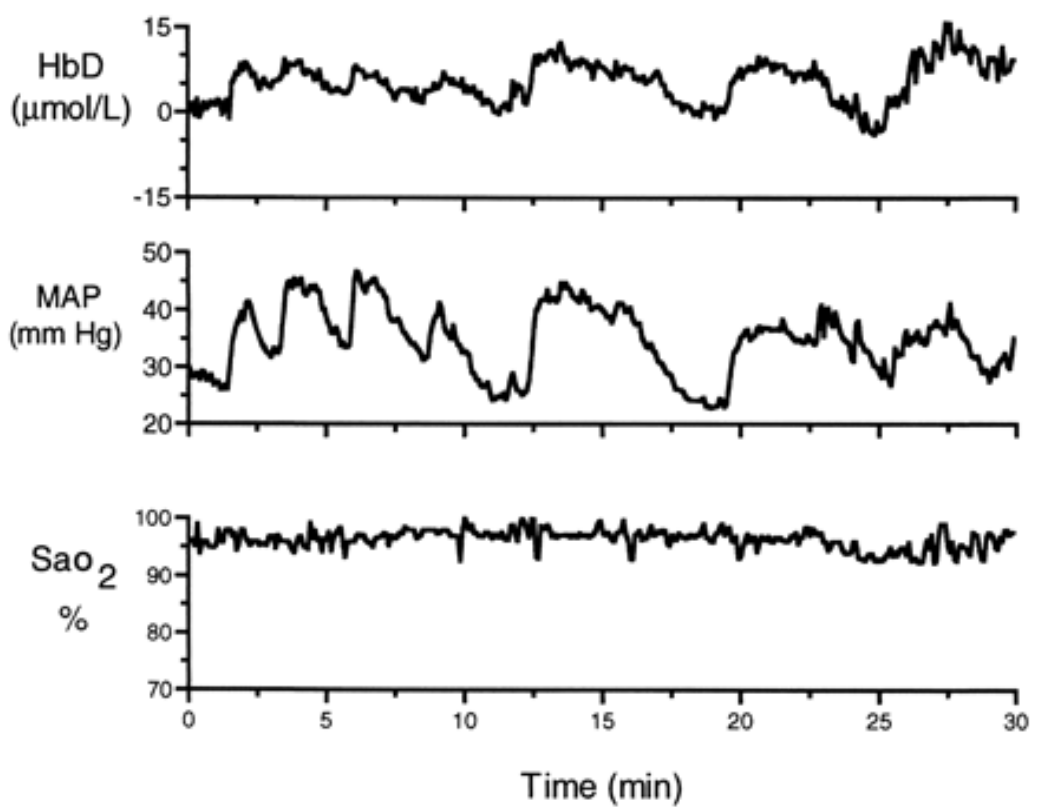

Fig. 1a. Example 1: Patient with loss of autoregulation and concordance of MAP and NIRS measurement of intravascular oxygenation $(\mathrm{HbD})$. This patient had an unfavorable outcome.
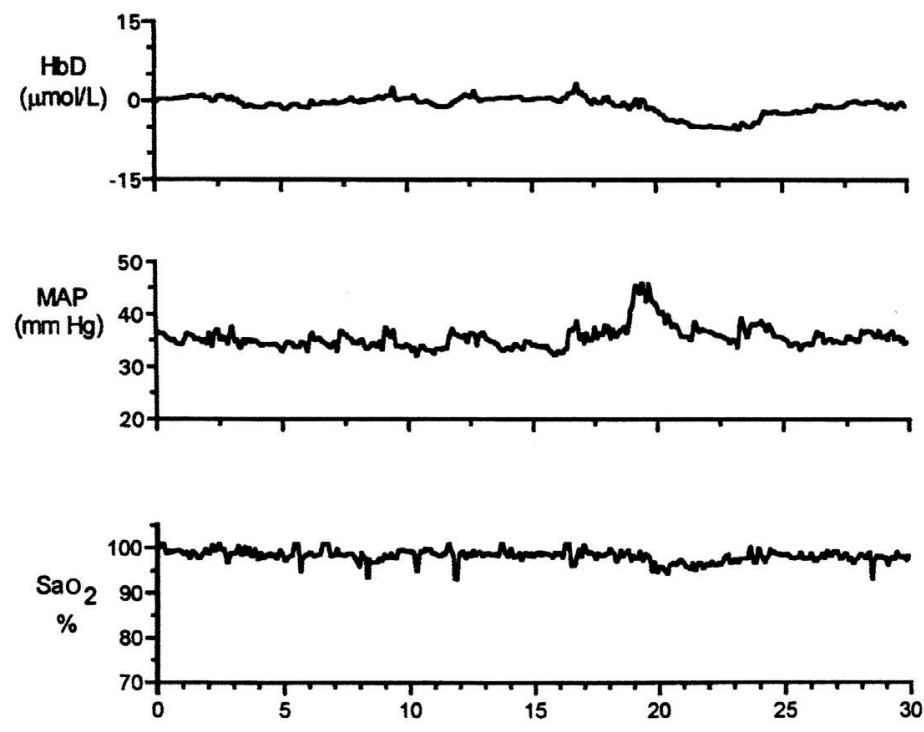

Time $(\min )$

Fig. 1b. Example 2: Maintenance of autoregulation (Tsuji, 2000) 
Hahn et al., 2010; Lemmers et al., 2006; Morren et al., 2003; Munro et al., 2004, 2005; O'Leary et al., 2009; Seri, 2006; Tsuji et al., 2000; Wong et al., 2008) In a recent study 23 infants with a mean gestational age of $26.7+/-1.4$ weeks were observed with NIRS. They were found to have periods of loss of cerebral autoregulation which were more profound with lower, longer lasting MABPs. There was no correlation with head ultrasound (HUS) findings as measure of short term outcome. (Gilmore et al., 2011)

A study followed changes in cerebral NIRS in ventilated preterm infants and found frequent periods of loss of autoregulation. (Lemmers et al., 2006). Vanderhaegen stresses the important contribution of pCO2 to cerebral blood flow, which may possibly override autoregulation. (Vanderhaegen et al., 2010) Hoffmann manipulated pCO2 in neonates undergoing cardiac surgery to improve cerebral blood flow. (Hoffman et al., 2005) According to another study by Vanderhaegen in 11 ELBWS blood glucose may play a role in influencing oxygenation. (Kurth et al., 1995)

\subsection{Cerebral hypoxia}

Cerebral hypoxia is a feared event as it translates to long-term morbidity and mortality. There is not enough data available linking a specific duration of hypoxia and levels of rSO2 or TOI while in the NICU with outcomes. There are no absolute numbers as reference in the human neonate. A piglet study from 2007 demonstrated changes seen on brain autopsy $72 \mathrm{~h}$ after the animal spent $30 \mathrm{~min}$. with $\mathrm{rSO} 2-\mathrm{c}$ of $<40 \%$. (Hou et al., 2007) It is not certain whether observations of concerning low levels of r-SO2/TOI in cardiac patients (Dullenkopf et al., 2003; Sorensen et al., 2008; van Bel et al., 2008; Wolf \& Greisen, 2009) apply to infants with other diagnoses.

\subsection{Cerebral hyperoxia}

Cerebral hyperoxia in the critically ill neonate may occur by 2 mechanisms: either as hyperoxygenation during the reperfusion phase of severe hypoxic ischemic encephalopathy most commonly occurring in neonates after perinatal birth depression or from decreased brain metabolism as seen in critical patients when blood flow is uncoupled from O2 (Toet, 2006; Wolf \& Greisen, 2009). Either scenario is concerning for a poor long-term prognosis. The overall clinical situation needs to be taken into consideration as cerebral rSO2 in well preterm neonates has also been reported to be high in the first days of life. (Sorensen et al., 2009).

\section{Renal NIRS}

Renal rSO2 is higher than cerebral $\mathrm{rSO} 2$. McNeill reported that trends in cerebral and renal NIRS during the first 21 days of life mirror each other. Short-term and long-term variability of $\mathrm{r}-\mathrm{SO} 2$ is small. Saturation changes exceeding $>20 \%$ from baseline would be reason for concern and may indicate compromised perfusion. Several investigators report use in patients with shock or during surgery. Measurements of the renal rSO2 give insight into peripheral perfusion in general and into renal end-organ function. Using renal $\mathrm{rSO} 2$ in conjunction with cerebral $\mathrm{rSO} 2$ has been reported to give more and sometimes earlier insights into evolving pathology such as shock. (Cohn et al., 2003; Hoffman et al., 2003, 2004) See figure 2 . 


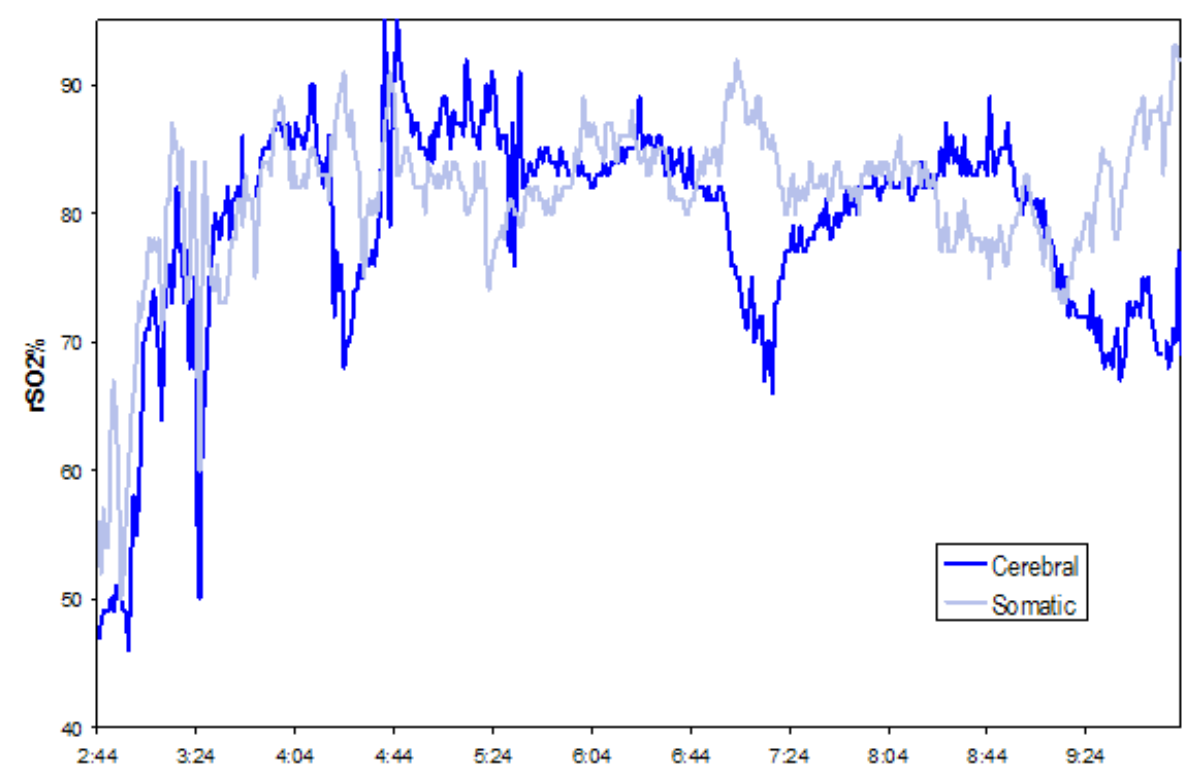

Fig. 2. Two-site NIRS trends from a patient undergoing resuscitation from hypovolemic/septic shock. Early aggressive resuscitation with fluid and epinephrine to normal regional $\mathrm{rSO} 2$ values restored urine output. The effect of changes in $\mathrm{pCO} 2$ on cerebral blood flow are evident at 0700 . The mirror changes in cerebral and somatic rSO2 suggest that total cardiac output was relatively limited but that the distribution changed.(Hoffman et al., 2007)

\section{Splanchnic (gut) NIRS}

Monitoring the GI tract as opposed to monitoring the brain or kidneys is more complex since the gut is a hollow or gas and stool filled, moving structure, in close proximity of stomach and bladder, which could affect its position and functioning. Proper probe placement may therefore be a challenge. In addition movements of the baby and pull on electrodes are more likely. A recent small study by Gillam-Krakauer et al. using Doppler confirmed that splanchnic NIRS reflects bloodflow to the small intestine. (Gillam-Krakauer et al., 2011)

McNeill's study of splanchnic/abdominal rSO2 in healthy preterm infants between day 0 and day 21 found that baseline changed over time. Overall abdominal rSO2 values were significantly lower than cerebral and renal values. The baseline increased over time. When comparing patients born at 32 and 33 weeks to those born at 29 and 30 weeks gestation, higher weekly means were observed in the $2^{\text {nd }}$ week of life in the older group. (McNeill et al., 2010, 2011)

These changes too may indicate regional developmental maturation. For abdominal rSO2 long- and short-term variability is much higher and exceeds $20 \%$. It may be associated with 
clinical and caregiving events and warrants further investigation/characterization. (McNeill et al., 2010, 2011)

Cortez found higher splanchnic rSO2-s and variability to be associated with a healthy gut, whereas infants with necrotizing enterocolitis, a condition of devastating bowel inflammation, had low splanchnic rSO2s and decreased variability. (Cortez et al., 2010, 2011)

\section{Clinical events observed with NIRS}

To further demonstrate the extent of topics and studies, examples of some clinical scenarios are listed. Referenced articles date back to 2000. The articles quoted are found in the bibliography. They are representative of the scope of interest.

\subsection{Unstable neonates}

Respiratory distress (Lemmers et al., 2006; Meek et al., 1998)

ECMO (Benni et al., 2005; Rais-Bahrami et al., 2006)

Pediatric Surgery (Dotta et al., 2005)

Cardiac disease pre-, intra, post op (Abdul-Khaliq et al., 2002; Hoffman et al., 2003; Johnson, 2009; Kurth et al., 2001; Li et al., 2008; Redlin et al., 2008; Seri, 2006)

Patent Ductus Arteriosus (Hüning et a., 2008; Keating et al., 2010; Lemmers et al., 2008, 2010; Meier et al., 2006; Underwood et al., 2006, 2007; Vanderhaegen et al., 2008; Zaramella et al., 2006)

CNS abnormalities HIE, PVL, PIH (Caicedo et al., 2011; De Smet et al., 2010; Morren et al., 2003; Munro et al., 2004, 2005; Wolf \& Greisen, 2009; Wong et al., 2008)

Greisen \& Borch , 2001; Hou et al. 2007; O'Leary et al., 2009; Sorensen \& Greisen, 2009; Toet, 2006; van Bel F et al., 2008; Vanderhaegen et al., 2009, 2010; Weiss, 2005; Verhaen et al. , 2010; Wolf \& Greisen , 2009)

Mechanical Ventilation (Noone et al., 2003; van Alfen-van der Velden et al., 2006; Verhagen et al., 2010)

Apnea (Payer et al., 2003; Yamamota et al., 2003)

Intensive Care (Limperopoulos et al., 2008)

Resuscitation (Baerts et al., 2010, 2011; Fuchs , 2011)

\subsection{Care giving}

Delivery room (Baenziger et al. ; Urlesberger et al., 2010)

Feedings (Baserga et al., 2003; Dave et al., 2008, 2009)

Blood transfusion (Bailey et al., 2010; Dani et al., 2010; Hess, 2010; van Hoften et al., 2010) *

Head ultrasound (van Alfen-van der Velden et al., 2008, 2009) 
Kangaroo care (Begum et al., 2008)

Endotracheal tube suctioning (Kohlhauser et al., 2000)

CPAP (Dani et al., 2007; van den Berg et al.,2009, 2010; Zaramella et al., 2006)

Blood draws from umbilical artery catheters (Bray et al., 2003; Hüning et al., 2007; Roll et al., 2006; Schulz et al., 2003) **

Stimuli, Pain (Bartocci et al., 2001, 2006; Holsti et al., 2011; Liao et al., 2010; Ozawa et al., 2010, 2011; Slater et al., 2007)

Posture/Position (Ancora et al., 2009, 2010; Pichler et al., 2001)

NIRS/EEG (van den Berg et al., 2009, 2010)

\subsection{Medications}

Caffeine (Tracy et al., 2010)

Dopamine (Wong et al., 2009)

Epinephrine (Pellicer et al., 2005)

Ibuprofen (Bray et al. 2003; Naulaers et al., 2005)

Indomethacin (Dave et al., 2008, 2009; Keating et al., 2010)

Morphine/Midozalam (van Alfen-van der Velden et al., 2006)

Propofol (Vanderhaegen et al.,2009, 2010)

Surfactant (Fahnenstich et al., 1991; van den Berg et al., 2009, 2010)

*Blood transfusions too are a routine part of NICU care. 3 studies found increases in rSO2-c following transfusion, in addition 2 of the authors reported increase in splanchnic oxygenation and lastly one of the studies found increased renal rSO2 as well. These findings are overall encouraging. Dani however questions whether the increases in rSO2 are reflecting benefits or administration of a pro-oxidant. Another author is attempting to identify the need for transfusion by calculating splanchnic-cerebral oxygen ratios. Infants with low ratios pre-transfusion are more likely to improve post-transfusion. (Bailey et al., 2010 ; Dani et al., 2010; Hess, 2010; van Hoften et al., 2010)

**Blood draws from umbilical artery catheters decrease rSO2-c. Two reports conflict on whether volume or a rapid draw causes the decrease in rSO2. (Roll et al., 2006; Schulz et al., 2003)

\section{Conclusions}

NIRS is a fascinating technology with impressive potential. The opportunities to learn more about physiology and effects of therapy through monitoring with NIRS are limitless.

The literature reporting about NIRS in the clinical setting of the NICU is abundant. However published supporting scientific evidence for the use of NIRS in neonatology has limitations. There are no large multi-center collaborative studies. The advent of NIRS has 
been affected by coinciding with the era of limited research funding for large clinical studies.

Studies are largely observational either observing a group of patients over time or following changes caused by therapeutic interventions (ECMO, heart surgery, transfusion, medications). Studies for the most part are small in patient numbers and short in time of observation. Study protocols observing the same phenomenon are often distinctly different from each other. Devices used may differ from trial to trial as well. All this can contribute to differences in study results. Due to the differences in study design meta-analysis, as an opportunity to obtain more robust results from a large number of trials and patients, may not be an option. Cerebral NIRS measurements are the most researched and incorporated into daily care. There is some consensus regarding critical lower limits of cerebral oxygenation (Wolf \& Greisen, 2009; Wider, 2009). In addition the patient is accepted as his own control, using the NIRS monitor as a trend monitor. (van Bel et al., 2008).

For the future of NIRS monitoring in the NICU, it may be necessary for another NIH panel to be called to review the existing evidence obtained since the initial group met in 1999 and devise a hopefully low budget strategy to validate NIRS in the NICU further. Larger, randomized trials will be needed. Blinding would not be useful unless normative data is obtained. Unblinded studies would allow interventions based on NIRS measurements and observe possible benefits. An anecdotal example was a rotated ECMO cannula that led to a steep decrease in cerebral r-SO2 with all other vital signs remaining unchanged. The caregivers responded immediately avoiding adverse consequences. Greisen in a paper from November 2011 estimates one needs to study 4000 infants with cerebral oximetry to have the power to detect the reduction of a clinically relevant endpoint, such as death or neurodevelopmental handicap, by 20\%. (Greisen et al., 2011)

In the meantime, NIRS monitors could be further improved to make interpretation of data easier:

While the information gained is tempting, interpretation of data takes experience. NIRS does not stand alone. It needs to be viewed in context of other occurring physiologic changes. Recently data collection and interpretation has been made easier and more precise by the increasing ability to synchronize collection of different data points and thus link NIRS observations, possibly from multiple channels, with vital signs, EEG, interventions, medications, stimulation and care giving events. At this point this technology is not generally available.

Eventually more channels to measure greater than 3 sites, allowing for more than one cerebral site plus somatic sites, may be needed.

Once norms are established for cerebral, renal and splanchnic sites, normal limits at each site for different gestational and postnatal ages could be indicated on the monitor. Alarms could signal when a patient's rSO2-c is outside the normal range. Variability could be reported both by percent change and change over time, also possibly in reference to gestational age for the observed organ. Incorporation of the ability for the monitor to calculate physiologic equations like FTOE or cerebral blood flow could give more value to NIRS monitoring.

Will those changes improve life and care in the NICU for patients and staff? Perhaps. Possibly clinicians find themselves confronted by unexpected physiology and new problems 
to solve. Now it is time to prove benefits of using the NIRS technology by decreasing adverse events in day-to-day patient care and improving outcome.

Greisen summarized the current situation in an article published recently:

"On the one hand, cerebral oximetry can potentially become inexpensive as it is based on technology that can be mass produced. Also, the probe may be miniaturized and integrated with the electronics into a soft 'plaster' that may stick to the skin of the head of tiny infants and need little attention. Solid evidence of benefit to patients will create a large market. Evidence of benefit of an instrument using public domain technology can serve as a platform for healthy competition on user-friendliness and price. On the other hand, what will happen if the clinical use of cerebral oximetry is not developed in a rational, evidence-based format? Then it may become another randomly applied expensive technology. Cerebral oximetry will be supported by anecdotal evidence, expert opinion, active branding and marketing. The consequences include unnecessary disturbances and risks to a very vulnerable group of patients and depletion of scarce healthcare resources".

(Greisen et al., 2011)

In closing, this chapter is not a manual for patient management. It demonstrated the implementation of a new tool as well as the temptations and hurdles faced by investigators and clinicians using a new promising device, which the author herself understands from both observation and personal experience.

\section{Acknowledgment}

We would like to thank Michelle Carretero for her help with the preparation of this chapter.

\section{References}

Abdul-Khaliq $\mathrm{H}$ et al. 2002 Cerebral oxygen monitoring during neonatal cardiopulmonary bypass and deep hypothermic circulatory arrest. Thorac Card Surg 50; 77-81

Ancora G, Maranella E, Aceti A, Pierantoni L, Grandi S, Corvaglia L, FaldellaG. Effect of posture on brain hemodynamics in preterm newborns not mechanically ventilated. Neonatology. 2010; 97(3):212-7. Epub 2009 Oct 29.

Baenziger O, Stolkin F, Keel M, von Siebenthal K, Fauchere JC, Das Kundu S, Dietz V, Bucher HU, Wolf M. The influence of the timing of cord clamping on postnatal cerebral oxygenation in preterm neonates: a randomized, controlled trial.

Baerts W, Lemmers PM, van Bel F. Cerebral oxygenation and oxygen extraction in the preterm infant during desaturation: effects of increasing $\mathrm{FiO}(2)$ to assist recovery. Neonatology. 2011; 99(1):65-72. Epub 2010 Jul 15.

Bailey SM, Hendricks-Muñoz KD, Wells JT, Mally P. Packed red blood cell transfusion increases regional cerebral and splanchnic tissue oxygen saturation in anemic symptomatic preterm infants. Am J Perinatol. 2010 Jun;27(6):445-53. Epub 2010 Jan 22.

Bartocci M, Bergqvist LL, Lagercrantz H, Anand KJ. Pain activates cortical areas in the preterm newborn brain. Pain. 2006 May;122(1-2):109-17. Epub 2006 Mar 13. 
Bartocci M, Winberg J, Papendieck G, Mustica T, Serra G, Lagercrantz H. Cerebral hemodynamic response to unpleasant odors in the preterm newborn measured by near-infrared spectroscopy. Pediatr Res. 2001 Sep; 50(3):324- 30.

Baserga MC, Gregory GA, Sola A. Cerebrovascular response in small preterm infants during routine nursery gavage feedings. Biol Neonate. 2003;83(1):12-8.

Begum EA, Bonno M, Ohtani N, Yamashita S, Tanaka S, Yamamoto H, Kawai M, Komada Y. Cerebral oxygenation responses during kangaroo care in low birth weight infants. BMC Pediatr. 2008 Nov 7;8:51.

Benni PB, Chen B, Dykes FD, Wagoner SF, Heard M, Tanner,AJ, Young TL, Rais-Bahrami K, Rivera O, Short BL. Validation of the CAS neonatal NIRS system by monitoring voECMO patients: preliminary results. Adv Exp Med Biol. 2005;566:195-201.

Bray M, Stucchi I, Fumagalli M, Pugni L, Ramenghi L, Agosti M, Mosca F. Blood withdrawal and infusion via umbilical catheters: effect on cerebral perfusion and influence of ibuprofen. Biol Neonate. 2003;84(3):187-93.

Caicedo A, De Smet D, Vanderhaegen J, Naulaers G, Wolf M, Lemmers P, Van Bel F, Ameye L, Van Huffel S. Impaired cerebral autoregulation using near-infrared spectroscopy and its relation to clinical outcomes in premature infants. Adv Exp Med Biol. 2011; 701:233-9

Cantagrel S, Cloarec S, Suc AL, Chamboux C, Tessier V, Saliba E, Laugier J. Consequences of pulmonary inflations (sighs) on cerebral haemodynamics in neonates ventilated by high-frequency oscillation. Acta Paediatr. 1999 Sep;88(9):1004-8.

Cohn SM et al. NIRS in resuscitation. J Trauma 2003:54;S199-S202.

Cortez J, Gupta M, Amaram A, Pizzino J, Sawhney M, Sood BG. Noninvasive evaluation of splanchnic tissue oxygenation using near-infrared spectroscopy in preterm neonates. J Matern Fetal Neonatal Med. 2011 Apr; 24(4):574-82. Epub 2010 Sep 9

Dani C et al. 2007 Brain haemodynamic effects of nasal CPAP in preterm infants of less than 30 weeks gestation. Acta Pediatrica ISSN 0803-5253n.pdf

Dani C, Bertini G, Pezzati M, Pratesi S, Filippi L, Tronchin M, Rubaltelli FF. Brain hemodynamic effects of doxapram in preterm infants. Biol Neonate. 2006;89(2):6974. Epub 2005 Sep 12.

Dani C, Pratesi S, Fontanelli G, Barp J, Bertini G. Blood transfusions increase cerebral, splanchnic, and renal oxygenation in anemic preterm infants. Transfusion. 2010 Jun; 50(6):1220-6. Epub 2010 Jan 22

Dave V, Brion LP, Campbell DE, Scheiner M, Raab C, Nafday SM. Splanchnic tissue oxygenation, but not brain tissue oxygenation, increases after feeds in stable preterm neonates tolerating full bolus orogastric feeding. J Perinatol. 2009 Mar;29(3):213-8. Epub 2008 Nov 20

Dave V, Brion LP, Campbell DE, Scheiner M, Raab C, Nafday SM. Splanchnic tissue oxygenation, but not brain tissue oxygenation, increases after feeds in stable preterm neonates tolerating full bolus orogastric feeding. J Perinatol. 2009 Mar;29(3):213-8. Epub 2008 Nov 20.

De Smet D, Jacobs J, Ameye L, Vanderhaegen J, Naulaers G, Lemmers P, van Bel F, Wolf M, Van Huffel S. The partial coherence method for assessment of impaired cerebral autoregulation using near-infrared spectroscopy: potential and limitations. Adv Exp Med Biol. 2010; 662:219-24. 
Delpy DT, Cope MC, Cady EB, Wyatt JS, Hamilton PA, Hope PL, Wray S, Reynolds EO. Cerebral monitoring in newborn infants by magnetic resonance and near infrared spectroscopy. Scand J Clin Lab Invest Suppl. 1987;188:9-17.

Dotta A et al. 2005 Effects of surgical repair of congenital diaphragmatic hernia on cerebral hemodynamics evaluated by NIRS. J Ped Surg 40; 1748-1752

Dullenkopf A et al. 2003 measurement of cerebral oxygenation state in anesthetized children using the INVOS 5100 cerebral oximeter. Ped Anesth 13; 384-391.pdf

Dullenkopf A et al. 2003 measurement of cerebral oxygenation state in anesthetized children using the INVOS 5100 cerebral oximeter. Ped Anesth 13; 384-391

Edwards AD, Wyatt JS, Richardson C, Delpy DT, Cope M, Reynolds EO. Cotside measurement of cerebral blood flow in ill newborn infants by near infrared spectroscopy. Lancet. 1988 Oct 1;2(8614):770-1.

Elwell CE, Henty JR, Leung TS, Austin T, Meek JH, Delpy DT, Wyatt JS. Measurement of $\mathrm{CMRO} 2$ in neonates undergoing intensive care using near infrared spectroscopy. Adv Exp Med Biol. 2005;566:263-8.

Fahnenstich $\mathrm{H}$ et al Relative changes in oxyhemoglobin, deoxyhemoglobin and intracranial blood volume during surfactant replacement therapy in infants with respiratory distress syndrome. Dev Pharmacol Ther. 1991; 17(3-4):150-3.

Feng $W$ et al. 2001 Influence of overlying tissue and probe geometry on the sensitivity of a NIR tissue oximeter. Physiol Measures 22; 201-208.pdf

Ferrari M et al. 2004 Principles, techniques and limitations of NIRS. Can J Appl Physiol 29; 463-487.

Fuchs E, 2011 Brain oxygenation monitoring during neonatal resuscitation of very low birth weight infants, Journal of Perinatology advance online publication 18 August 2011; doi: 10.1038/jp.2011.110

Gilmore MM, Stone BS, Shepard JA, Czosnyka M, Easley RB, Brady KM-Relationship between cerebrovascular dysautoregulation and arterial blood pressure in the premature infant. Journal of Perinatology (2011) 31, 722-729; doi:10.1038/jp.2011.17; published online 3 March 2011

Gillam-Krakauer M. et al Abdominal Near-Infrared Spectroscopy Measurements Correlate with Superior Mesenteric Artery Doppler Ultrasound in Very Preterm Infants, PAS 2011, E-PAS20111421.216

Greisen G, Borch K. White matter injury in the preterm neonate: the role of perfusion. Dev Neurosci 2001; 23: 209-212.2005

Greisen $\mathrm{G}$ et al , Has the time come to use near-infrared spectroscopy as a routine clinical tool in preterm infants undergoing intensive care? Phil. Trans. R. Soc. A (2011) 369, 4440-4451 doi:10.1098/rsta.2011.0261

Hahn GH, Christensen KB, Leung TS, Greisen G. Precision of coherence analysis to detect cerebral autoregulation by near-infrared spectroscopy in preterm infants. J Biomed Opt. 2010 May-Jun; 15(3):037002.

Hess JR. Seeing red. Transfusion. 2010 Jun;50(6):1170-2. [Link to PubMed for fulltext: PMID: 20598099.

Hoffman GM et al. 2003 Two-site NIRS transcutaneous oximetry as a non-invasive indicator of mixed venous oxygen saturation in cardiac neonates. Anesthesiology 99; A1393 
Hoffman GM et al. 2004.NIRS-Derived Somatic and Cerebral Saturation Difference Provides Non-Invasive Real-Time Hemodynamic Assessment of Cardiogenic Shock and Riskof Anaerobic Metabolism Anesthesiology 2004; 101: A1448

Hoffman GM et al.2007 NONINVASIVE MONITORING OF CARDIAC OUTPUT: BENEFITS OFNIRS TECHNOLOGY Congenital CardToday - Cardiac Output 0607

Hoffman GM et al. 2005 Differential effects of carbon dioxide tension on cerebral and somatic oxygenation assessed by NIRS. Anesthesiology 103; A1374.

Holsti L, Grunau RE, Shany E. Assessing pain in preterm infants in the neonatal intensive care unit: moving to a 'brain-oriented' approach. Pain Manag. 2011 Mar 1; 1(2):171179

Hou X et al. 2007 Research on the relationship between brain anoxia at different regional oxygen saturations and brain damage using NIRS. Physiol Measures 28; 1251-1265

Hüning BM, Asfour B, König S, Hess N, Roll C. Cerebral blood volume changes during closure by surgery of patent ductus arteriosus. Arch Dis Child Fetal Neonatal Ed. 2008 Jul;93(4):F261-4. Epub 2008 Feb 5.

Hüning BM, Horsch S, Roll C. Blood sampling via umbilical vein catheters decreases cerebral oxygenation and blood volume in preterm infants. Acta Paediatr. 2007 Nov;96(11):1617-21.

Johnson BA 2009 Near-Infrared Spectroscopy in Neonates Before

Keating P, Verhagen E, van Hoften J, ter Horst H, Bos AF. Effect of indomethacin infused over 30 minutes on cerebral fractional tissue oxygen extraction in preterm newborns with a patent ductus arteriosus. Neonatology.2010;98(3):232-7. Epub 2010 Apr 13

Kohlhauser C et al. 2000 Effects of Endotracheal Suctioning on NIRS - Ped Pulmon 29; 270275

Kurth CD et al. 1995 A dynamic phantom brain model for NIRS. Phys Med Biol 40; 20792092.

Kurth CD et al. 2001 Cerebral oxygen saturation before congenital heart surgery. Ann Thorac Surg 72; 187-192

Lemmers PM, Molenschot MC, Evens J, Toet MC, van Bel F. Is cerebral oxygen supply compromised in preterm infants undergoing surgical closure for patent ductus arteriosus? Arch Dis Child Fetal Neonatal Ed. 2010 Nov;95(6):F429-34. Epub 2010 Jun 28.

Lemmers PM, Toet M, van Schelven LJ, van Bel F. Cerebral oxygenation and cerebral oxygen extraction in the preterm infant: the impact of respiratory distress syndrome. Exp Brain Res. 2006 Aug; 173(3):458-67. Epub 2006 Feb 28

Lemmers PM, Toet MC, van Bel F. Impact of patent ductus arteriosus and subsequent therapy with indomethacin on cerebral oxygenation in preterm infants. Pediatrics. 2008 Jan;121(1):142-7

Lemmers PM, van Bel F. Left-to-right differences of regional cerebral oxygen saturation and oxygen extraction in preterm infants during the first days of life. Pediatr Res. 2009 Feb;65(2):226-30

Lemmers PMA, Toet M, van Schelven LJ, van Bel F. Cerebral oxygenation and cerebral oxygen extraction in the preterm infant: the impact of respiratory distress syndrome. Exp Brain Res 2006; 173: 458-467. 
Li J, Zhang G, Holtby H, Guerguerian AM, Cai S, Humpl T, Caldarone CA, Redington AN, Van Arsdell GS. The influence of systemic hemodynamics and oxygen transport on cerebral oxygen saturation in neonates after the Norwood procedure. J Thorac Cardiovasc Surg. 2008 Jan;135(1):83-90, 90.e1-2.

Liao SM, Gregg NM, White BR, Zeff BW, Bjerkaas KA, Inder TE, Culver JP. Neonatal hemodynamic response to visual cortex activity: high-density near-infrared spectroscopy study. J Biomed Opt. 2010 Mar-Apr;15(2):026010

Limperopoulos C, Gauvreau KK, O'Leary H, Moore M, Bassan H, Eichenwald EC, Soul JS, Ringer SA, Di Salvo DN, du Plessis AJ. Cerebral hemodynamic changes during intensive care of preterm infants. Pediatrics. 2008 Nov;122(5):e1006-13. Epub 2008 Oct 17.

Madsen PL et al. 2000 Interference of Cerebral NIR in patients with Icterus Anesth and Analgesia 90 489-93.pdf

McNeill S, Gatenby JC, McElroy S, Engelhardt B. Normal cerebral, renal and abdominal regional oxygen saturations using near-infrared spectroscopy in preterm infants. J Perinatol. 2011 Jan; 31(1):51-7. Epub 2010 Jun 10.

McQuillen PS, Nishimoto MS, Bottrell CL, Fineman LD, Hamrick SE, Glidden DV, Azakie A, Adatia I, Miller SP. Regional and central venous oxygen saturation monitoring following pediatric cardiac surgery: concordance and association with clinical variables. Pediatr Crit Care Med. 2007 Mar;8(2):154-60.

Meek JH, Tyszczuk L, Elwell CE, Wyatt JS. Cerebral blood flow increases over the first three days of life in extremely preterm neonates. Arch Dis Child Fetal Neonatal Ed. 1998 Jan; 78(1):F33-7

Meier SD, Eble BK, Stapleton GE, Morales DL, Chang AC, Andropoulos DB. Mesenteric oxyhemoglobin desaturation improves with patent ductus arteriosus ligation. J Perinatol. 2006 Sep;26(9):562-4.

Meier SD, Eble BK, Stapleton GE, Morales DL, Chang AC, Andropoulos DB. Mesenteric oxyhemoglobin desaturation improves with patent ductus arteriosus ligation. J Perinatol. 2006 Sep; 26(9):562-4.

Menke J et al. 2003 Reproducability of NIRS in neonates - Biol Neonate 83; 6-11

Morren G, Naulaers G, Lemmerling P, Van Huffel S, Casaer P, Devlieger H. Quantitation of the concordance between cerebral intravascular oxygenation and mean arterial blood pressure for the detection of impaired autoregulation. Adv Exp Med Biol. 2003;510:403-8.

Mott AR, Alomrani A, Tortoriello TA, Perles Z, East DL, Stayer SA. Changes in cerebral saturation profile in response to mechanical ventilation alterations in infants with bidirectional superior cavopulmonary connection. Pediatr Crit Care Med. 2006 Jul;7(4):346-50.

Munro MJ, Walker AM, Barfield CP. Hypotensive extremely low birth weight infants have reduced cerebral blood flow. Pediatrics. 2004 Dec;114(6):1591-6. Erratum in: Pediatrics. 2005 Jun;115(6):1794-5

Nagdyman N, Fleck T, Barth S, Abdul-Khaliq H, Stiller B, Ewert P, Huebler M, Kuppe H, Lange PE. Relation of cerebral tissue oxygenation index to central venous oxygen saturation in children. Intensive Care Med. 2004 Mar;30(3):468-71. Epub 2004 Jan 13 
Naulaers G, Delanghe G, Allegaert K, Debeer A, Cossey V, Vanhole C, Casaer P, Devlieger $\mathrm{H}$, Van Overmeire B. Ibuprofen and cerebral oxygenation and circulation. Arch Dis Child Fetal Neonatal Ed. 2005 Jan; 90(1):F75-6.

Naulaers G, Morren G, Van Huffel S, Casaer P, Devliegar H. Cerebral tissue oxygenation index in very premature infants. Arch Dis Child Fetal Neonatal Ed 2002; 87: F189F192.

Noone MA, Sellwood M, Meek JH, Wyatt JS. Postnatal adaptation of cerebral blood flow using near infrared spectroscopy in extremely preterm infants undergoing highfrequency oscillatory ventilation. Acta Paediatr. 2003 Sep;92(9):1079-84.

O'Leary H, Gregas MC, Limperopoulos C, Zaretskaya I, Bassan H, Soul JS, Di Salvo DN, du Plessis AJ. Elevated cerebral pressure passivity is associated with prematurityrelated intracranial hemorrhage. Pediatrics. 2009 Jul;124(1):302-9.

Ozawa M, Kanda K, Hirata M, Kusakawa I, Suzuki C. Influence of repeated painful procedures on prefrontal cortical pain responses in newborns. Acta Paediatr. 2011 Feb; 100(2):198-203. doi: 10.1111/j.1651-2227.2010.02022.x. Epub 2010 Oct 8.

Palliation of Hypoplastic Left Heart Syndrome Ann Thorac Surg 2009;87:571-9)

Payer C, Urlesberger B, Pauger M, Müller W. Apnea associated with hypoxia in preterm infants: impact on cerebral blood volume. Brain Dev. 2003 Jan;25(1):25-31.

Pellicer A, Valverde E, Elorza MD, Madero R, Gayá F, Quero J, Cabañas F. Cardiovascular support for low birth weight infants and cerebral hemodynamics: a randomized, blinded, clinical trial. Pediatrics. 2005 Jun;115(6):1501-12.

Pichler G, Schmölzer G, Müller W, Urlesberger B. Body position-dependent changes in cerebral hemodynamics during apnea in preterm infants. Brain Dev. 2001 Oct;23(6):395-400.

Pichler G, Urlesberger B, Schmölzer G, Müller W. Effect of tilting on cerebral haemodynamics in preterm infants with periventricular leucencephalomalacia. Acta Paediatr. 2004 Jan; 93(1):70-5.

Pichler G, van Boetzelar MC, Müller W, Urlesberger B. Effect of tilting on cerebral hemodynamics in preterm and term infants. Biol Neonate. 2001;80(3):179-85.

Rais-Bahrami K et al. 2006 Validation of a noninvasive neonatal cerebral oximeter in venousvenous ECMO patients. J Perinatol 26 628-635

Redlin M, Koster A, Huebler M, Boettcher W, Nagdyman N, Hetzer R, Kuppe H, Kuebler WM. Regional differences in tissue oxygenation during cardiopulmonary bypass for correction of congenital heart disease in neonates and small infants: relevance of near-infrared spectroscopy. J Thorac Cardiovasc Surg. 2008 Oct;136(4):962-7.

Roche-Labarbe N, Carp SA, Surova A, Patel M, Boas DA, Grant PE, Franceschini MA. Noninvasive optical measures of $\mathrm{CBV}, \mathrm{StO}(2), \mathrm{CBF}$ index, and $\mathrm{rCMRO}(2)$ in human premature neonates' brains in the first six weeks of life. Hum Brain Mapp. 2010 Mar; 31(3):341-52. Erratum in: Hum Brain Mapp. 2011 Jul; 32(7):1179.

Roll C, Hüning B, Käunicke M, Krug J, Horsch S. Umbilical artery catheter blood sampling volume and velocity: impact on cerebral blood volume and oxygenation in verylow-birthweight infants. Acta Paediatr. 2006 Jan;95(1):68-73.

Schrod L, Walter J. Effect of head-up body tilt position on autonomic function and cerebral oxygenation in preterm infants. Biol Neonate. 2002;81(4):255-9. 
Schulz G, Keller E, Haensse D, Arlettaz R, Bucher HU, Fauchère JC. Slow blood sampling from an umbilical artery catheter prevents a decrease in cerebral oxygenation in the preterm newborn. Pediatrics. 2003 Jan;111(1):e73-6.

Seri I. Management of hypotension and low systemic blood flow in the very low birth weight neonate during the first postnatal week. Journal of Perinatology (2006) 26, S8S13.

Slater R, Cantarella A, Gallella S, Worley A, Boyd S, Meek J, Fitzgerald M. Cortical pain responses in human infants. J Neurosci. 2006 Apr 5;26(14):3662-6.

Slater R, Fitzgerald M, Meek J. Can cortical responses following noxious stimulation inform us about pain processing in neonates? Semin Perinatol. 2007 Oct;31(5):298-302. Review.

Sorensen LC, Greisen G. The brains of very preterm newborns in clinically stable condition may be hyperoxygenated. Pediatrics. 2009 Nov;124(5):e958-63. Epub 2009 Oct 19.

Sorensen LC, Leung TS, Greisen G. Comparison of cerebral oxygen saturation in premature infants by near-infrared spatially resolved spectroscopy: observations on probedependent bias. J Biomed Opt. 2008 Nov-Dec; 13(6):064013

Soul JS, Hammer PE, Tsuji M, Saul JP, Bassan H, Limperopoulos C, Disalvo DN, Moore M, Akins P, Ringer S, Volpe JJ, Trachtenberg F, du Plessis AJ. Fluctuating pressurepassivity is common in the cerebral circulation of sick premature infants. Pediatr Res. 2007 Apr;61(4):467-73.

Takami T, Sunohara D, Kondo A, Mizukaki N, Suganami Y, Takei Y, Miyajima T, Hoshika A. Changes in cerebral perfusion in extremely LBW infants during the first $72 \mathrm{~h}$ after birth. Pediatr Res. 2010 Nov; 68(5):435-9.

Tobias JD. Cerebral oximetry using near-infrared spectroscopy aids in the diagnosis of interrupted aortic arch. J Intensive Care Med. 2008 Sep-Oct;23(5):335-7.

Toet Mona C. Cerebral Oxygenation and Electrical Activity After Birth Asphyxia: Their Relation to Outcome Pediatrics 2006; 117;333-339

Tracy MB, Klimek J, Hinder M, Ponnampalam G, Tracy SK. Does caffeine impair cerebral oxygenation and blood flow velocity in preterm infants? Acta Paediatr. 2010 Sep; 99(9):1319-23. doi: 10.1111/j.1651-2227.2010.01828.x.

Tsuji M 2000 Cerebral intravascular oxygenation correlates with mean arterial pressure in critically ill premature infants. Pediatrics 106; 625-632.

Underwood MA, Milstein JM, Sherman MP. Near-infrared spectroscopy as a screening tool for patent ductus arteriosus in extremely low birth weight infants. Neonatology. 2007;91(2):134-9. Epub 2006 Nov 20.

Urlesberger B J et al. Regional Oxygen Saturation of the Brain and Peripheral Tissue during Birth Transition of Term Infants Pediatrics 2010 epub[1].

van Alfen-van der Velden AA, Claessen VP, Hopman JC, Klaessens JH, Sengers RC, Liem KD. Changes in cerebral oxygenation and hemodynamics during cranial ultrasound in preterm infants. Brain Dev. 2009 Jun;31(6):427-34. Epub 2008 Oct 5.

van Alfen-van der Velden AA, Hopman JC, Klaessens JH, Feuth T, Sengers RC, Liem KD. Effects of midazolam and morphine on cerebral oxygenation and hemodynamics in ventilated premature infants. Biol Neonate. 2006;90(3):197-202. Epub 2006 May 22.

van Bel F et al. 2008 Monitoring Neonatal Regional Cerebral Oxygen Saturation in Clinical Practice: Value and Pitfalls. Neonatology 2008; 94:237-244 DOI: 10.1159/000151642 
van den Berg E, Lemmers PM, Toet MC, Klaessens JH, van Bel F. Effect of the "InSurE" procedure on cerebral oxygenation and electrical brain activity of the preterm infant. Arch Dis Child Fetal Neonatal Ed. 2010 Jan;95(1):F53-8. Epub 2009 Aug 13.

van Hoften JC, Verhagen EA, Keating P, ter Horst HJ, Bos AF. Cerebral tissue oxygen saturation and extraction in preterm infants before and after blood transfusion. Arch Dis Child Fetal Neonatal Ed. 2010 Sep; 95(5):F352-8. Epub 2010 May 13

Vanderhaegen J, De Smet D, Meyns B, Van De Velde M, Van Huffel S, Naulaers G. Surgical closure of the patent ductus arteriosus and its effect on the cerebral tissue oxygenation. Acta Paediatr. 2008 Dec;97(12):1640-4. Epub 2008 Sep 11.

Vanderhaegen J, Naulaers G, Van Huffel S, Vanhole C, Allegaert K. Cerebral and systemic hemodynamic effects of intravenous bolus administration of propofol in neonates. Neonatology. 2010 Jun;98(1):57-63. Epub 2009 Dec 24.

Vanderhaegen J, Naulaers G, Vanhole C, De Smet D, Van Huffel S, Vanhaesebrouck S, Devlieger $\mathrm{H}$. The effect of changes in $\mathrm{tPCO} 2$ on the fractional tissue oxygen extraction--as measured by near-infrared spectroscopy--in neonates during the first days of life. Eur J Paediatr Neurol. 2009 Mar;13(2):128-34. Epub 2008 Jul 10.

Vanderhaegen J, Vanhaesebrouck S, Vanhole C, Casaer P, Naulaers G. The effect of glycaemia on the cerebral oxygenation in very low birthweight infants as measured by near-infrared spectroscopy. Adv Exp Med Biol. 2010;662:461-6.

Verhagen EA, Keating P, ter Horst HJ, Martijn A, Bos AF. Cerebral oxygen saturation and extraction in preterm infants with transient periventricular echodensities. Pediatrics. 2009 Jul;124(1):294-301

Verhagen EA, Ter Horst HJ, Keating P, Martijn A, Van Braeckel KN, Bos AF. Cerebral oxygenation in preterm infants with germinal matrix-intraventricular hemorrhages. Stroke. 2010 Dec; 41(12):2901-7. Epub 2010 Oct 21. www.ninds.nih.gov/news_and_events/proceedings/nirsworkshop1999.htm

Wassenaar EB et al. 2005 Reliability of NIRS in people with dark skin pigmentation. J Clin Monitoring and Computing 19; 195-199.pdf

Weiss M 2005 NIRS Cerebral Oxygenation Reading in Neonates and Infants and SvO2 - Ped Anesth 15; 102-109.pdf(Validation)

Wider M. Hemodynamic Management and Regional Hemoglobin Oxygen Saturation (rSO2) of the Brain, Kidney and Gut, Neonatal Intensive Care, Vol. 22 No. 5, September 2009

Wolf M, Greisen G. Advances in near-infrared spectroscopy to study the brain of the preterm and term neonate. Clin Perinatol. 2009 Dec; 36(4):807-34

Wolf M, Greisen G. Advances in near-infrared spectroscopy to study the brain of the preterm and term neonate. Clin Perinatol. 2009 Dec;36(4):807-34, vi. Review.

Wong FY, Barfield CP, Horne RS, Walker AM. Dopamine therapy promotes cerebral flowmetabolism coupling in preterm infants. Intensive Care Med. 2009 Oct;35(10):177782. Epub 2009 Aug 1.

Wong FY, Leung TS, Austin T, Wilkinson M, Meek JH, Wyatt JS, Walker AM. Impaired autoregulation in preterm infants identified by using spatially resolved spectroscopy. Pediatrics. 2008 Mar;121(3):e604-11. Epub 2008 Feb 4 
Yamamoto A, Yokoyama N, Yonetani M, Uetani Y, Nakamura H, Nakao H. Evaluation of change of cerebral circulation by $\mathrm{SpO} 2$ in preterm infants with apneic episodes using near infrared spectroscopy. Pediatr Int. 2003 Dec; 45(6):661-4.

Yanowitz TD, Potter DM, Bowen A, Baker RW, Roberts JM. Variability in cerebral oxygen delivery is reduced in premature neonates exposed to chorioamnionitis. Pediatr Res. 2006 Feb;59(2):299-304.

Zaramella P, Freato F, Grazzina N, Saraceni E, Vianello A, Chiandetti L. Does helmet CPAP reduce cerebral blood flow and volume by comparison with Infant Flow driver CPAP in preterm neonates? Intensive Care Med. 2006 Oct;32(10):1613-9. Epub 2006 Aug 1.

Zaramella P, Freato F, Quaresima V, Ferrari M, Bartocci M, Rubino M, Falcon E, Chiandetti L. Surgical closure of patent ductus arteriosus reduces the cerebral tissue oxygenation index in preterm infants: a near-infrared spectroscopy and Doppler study. Pediatr Int. 2006 Jun;48(3):305-12. 


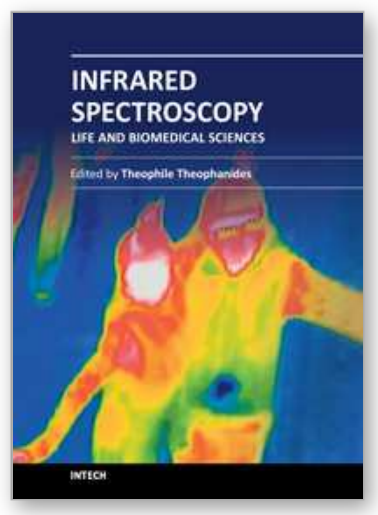

\author{
Infrared Spectroscopy - Life and Biomedical Sciences \\ Edited by Prof. Theophanides Theophile
}

ISBN 978-953-51-0538-1

Hard cover, 368 pages

Publisher InTech

Published online 25, April, 2012

Published in print edition April, 2012

This informative and state-of-the art book on Infrared Spectroscopy in Life sciences designed for researchers, academics as well as for those working in industry, agriculture and in pharmaceutical companies features 20 chapters of applications of MIRS and NIRS in brain activity and clinical research. It shows excellent FT-IR spectra of breast tissues, atheromatic plaques, human bones and projects assessment of haemodynamic activation in the cerebral cortex, brain oxygenation studies and many interesting insights from a medical perspective.

\title{
How to reference
}

In order to correctly reference this scholarly work, feel free to copy and paste the following:

Barbara Engelhardt and Maria Gillam-Krakauer (2012). Use of Near-Infrared Spectroscopy in the Management of Patients in Neonatal Intensive Care Units - An Example of Implementation of a New Technology, Infrared Spectroscopy - Life and Biomedical Sciences, Prof. Theophanides Theophile (Ed.), ISBN: 978-953-51-0538-1, InTech, Available from: http://www.intechopen.com/books/infrared-spectroscopy-life-andbiomedical-sciences/use-of-near-infrared-spectroscopy-in-the-management-of-patients-in-neonatal-intensivecare-units-a

\section{INTECH}

open science | open minds

\section{InTech Europe}

University Campus STeP Ri

Slavka Krautzeka 83/A

51000 Rijeka, Croatia

Phone: +385 (51) 770447

Fax: +385 (51) 686166

www.intechopen.com

\section{InTech China}

Unit 405, Office Block, Hotel Equatorial Shanghai

No.65, Yan An Road (West), Shanghai, 200040, China

中国上海市延安西路65号上海国际贵都大饭店办公楼405单元

Phone: +86-21-62489820

Fax: $+86-21-62489821$ 
(C) 2012 The Author(s). Licensee IntechOpen. This is an open access article distributed under the terms of the Creative Commons Attribution 3.0 License, which permits unrestricted use, distribution, and reproduction in any medium, provided the original work is properly cited. 